\title{
MENGKRITISI FAKTOR-FAKTOR KEGAGALAN AKADEMIK SISWA DALAM BELAJAR
}

\section{Muh. Misdar \\ Dosen Fakultas Ilmu \\ Tarbiyah dan Keguruan UIN Raden Fatah Palembang}

muhmisdar_uin@radenfatah.ac.id

\begin{abstract}
Changes and developments in education are identical to learning. Because learning is a means to change. Changes as learning outcomes can emerge changes in physical, intellectual, emotional and behavioral changes. Not all learning can achieve the above, systematic and systematic learning that can lead to these changes. The failure of learning is one of the obstacles to change. Deep understanding of the inhibiting factors of learning is one way to overcome them. Failure to learn is a trigger for academic failure achieved by students at school.

In this paper there are seven factors that lead to academic failure of students in school, among others: The active cycles experienced by students before they become the trigger for further failure, weaknesses in students in learning that are unclear what orientation and learning objectives in school, weak business those who have not yet shown a resilient effort in learning, low self-control that appears in the effort of low selfdiscipline in learning, lack of noble attitude that does not seem to like the heavy burden of learning, does not like challenges such as lethargy when added with assignments more learning assignments, low perceptions of learning success which usually do not have an effort to pursue higher achievement, hopes of going forward are very low.

All these factors must be packaged systematically so as not to become the biggest obstacle for students in learning not to fail in school. Basically, in schools and in madrasas the teacher has implemented an effort to reduce the failure. It's just that the way teachers do is very conventional, not yet giving contributive meaning to solving student learning failures. like giving assignments or recitation. During this time the task is interpreted in a way to overcome the weaknesses of students, the task should be interpreted as a functional positive attribution to the strengthening of the results of weaknesses or failures of student learning.
\end{abstract}

Keywords: Change, Academic Failure, Recitation 


\section{PENDAHULUAN}

Para pendidik yang bergelut dengan pembelajaran di lingkungan sekolah, terutama di lingkungan madrasah baik swasta maupun negeri, umumnya menunjukkan gejala kinerja yang berlaku umum, mereka jarang sekali menggali secara mendalam penyebab siswa-siswanya gagal dalam belajar. Mereka sulit menemukan mengapa mereka menghadapi masalah kegagalan dalam belajar siswanya. Sebagian besar masalah yang beraitan dengan kegagalan belajar siswa, digali dan dikritisi oleh para pendidiknya secara empirik melalui fenomena eksternal kepribadian siswa. Guru umumnya hanya menyoroti perilaku kegagalan belajar siswa bersifat sesaat dan muncul secara instan bersifat eksternal, jarang sekali dihubungkan dengan faktor-faktor internal, bersemayam dalam diri siswa. Boleh jadi kadang-kadang mereka hubungkan saja dengan faktor kehidupan siswa, seperti siswa yang gagal umumnya berhubungan dengan pekerjaan di luar sekolah.

Asumsi guru umumnya sangat dangkal terhadap kegagalan belajar siswa. Mereka umumnya menyoroti bahwa kegagalan belajar siswa hanya dikaji atau dilihat dari sudut empiris sehari-hari yang nyata dilakukan siswa. Seperti; diasumsikan dengan pengalaman atau pekerjaan siswa di luar jam sekolah, belum dikaji secara mendalam dari sudut internal kepribadian siswa, padahal kegagalan belajar siswa sangat dominan berakar dari dalam diri siswa itu sendiri, meskipun tidak dapat dipungkiri berakar pula dari luar diri siswa. Di antara hal-hal yang bersifat internal tersebut, adalah kepercayaan negatif yang berkepanjangan dalam diri siswa, ketidakberdayaan siswa terhadap problem-priblemnya dalam belajar, atau dapat pula disebabkan oleh perkiraan yang asumtif dan dangkal terhadap keberhasilan yang sangat rendah dalam diri siswa. Dari sudut pandang itulah selanjutnya patut dikaji secara mendalam bagaimana cara guru dan para pendidik lainnya memperkecil kegagalan belajar siswa pada suatu sekolah. Hal itu tidak terlepas dari pengaruh asumtif yang tertanam dalam diri guru, baik yang positif maupun negatif, yang telah mengakar jauh sebelumnya bahwa kegagalan siswa disebabkan oleh perilaku di luar diri siswa.

Dari paparan tersebut memperlihatkan terdapat ketidaksinkronisasi antara apa yang seharusnya terjadi dengan kegagalan akademik siswa dalam belajar dengan pandangan intelektual guru dan sekaligus cara mereka mengatasinya. 
Kadang-kadang kegagalan akademik siswa di sekolah-sekolah ataupun di madrasah swasta lebih rentan dibandingan dengan siswa-siswa di sekolah negeri, meskipun hal itu baru menunjukkan gejala asumtif. Belum dapat diketahui apakah permasalahan kegagalan akademik yang dialami siswa di sekolah berdampak pula terhadap kegagalan sekolah mereka. Dan apakah kegagalan pemahaman guru tetang cara mengatasinya berdampak pula terhadap keberhasilan siswa yang berkelanjutan.

\section{HASIL DAN PEMBAHASAN}

\section{A. Belajar Adalah Modal Dasar Pengembangan Akademik}

Sebelum belajar dilakukan harus lebih dahulu ditanamkan dalam pikiran setiap orang, baik orang tua mapun pendidik, bahwa sebagai sebuah proses menuju perubahan dan perkembangan, terutama perkembangan menuju kematangan bagi seorang siswa, bahwa belajar adalah menjadi satu-satunya cara yang dapat ditempuh dalam rangka merealisasi cara menuju perubahan dan perkembangan sebagaimana dimaksudkan tersebut, baik perkembangan yang berkaitan dengan perkembangan fisik, intelektual maupun emosional. Maka pilihan terhadap lembaga sekolah atau madrasah yang lazimnya dijadikan sebagai tempat belajar menjadi salah satu prinsip dasar yang dapat menentukan belajar seorang siswa. Karena walau bagaimanapun tempat belajar dalam konteks ini seperti sekolah dan madrasah pasti dapat mewarnai kehidupan belajarnya seorang siswa.

Karena di dalam belajar baik dalam pengertian umum maupun pengertian terbatas, akan ditemukan cara, proses dan lebih khusus materi belajar, yang kesemuanya itu secara tidak langsung dapat mengubah diri seorang. Secara fisik tentu saja akan megalami perubahan besar pada tinggi badan, dan secara emosional perubahan dapat merasakan senang ataupun susah ketika suasana belajar sedang berjalan, sedangkan secara intelektual perubahan dapat diwujudkan dari tidak mengerti menjadi mengerti. Oleh sebab itu belajar dalam pengertian menuju perubahan yang dimaksud, tidak semata-mata terpaku dengan aktivitas membaca dan menulis sebagaimana dipahami secara sederhana oleh siswa di sekolah, tetapi belajar tersebut secara konseptual harus dapat diartikulasikan sebagai upaya transformatif seseorang secara signifikan, mengembangkan diri dari tidak tahu menjadi tahu, dari tidak mengerti menjadi mengerti dan dari bodoh 
menjadi pintar Dari situlah selanjutnya belajar dapat dimaknai sebagai aktivitas perubahan menuju kehidupan yang lebih baik secara sistematis (Rahyubi, 2012:3).

Di dalam rangka menuju perubahan tersebut, menguraikan secara konkrit makna belajar sebagaimana disebutkan di atas sangatlah penting, terutama urgensi belajar sangat signifikan bagi setiap peserta didik dan pendidik, sehingga mereka semuanya dapat memahami makna belajar yang sesungguhnya, sehingga dengan pemahaman yang komprehensip, apa itu belajar dan bagaiamana urgensi belajar bagi perkembangan dan pertumbuhan bagi setiap siswa, diharapkan siswa dapat menemukan pola belajar yang sempurna, sehingga apa yang disebut dengan kegagalan belajar dapat dihindari. Dengan pengertian yang komprehensif tersebut gurupun, diharapkan dapat merumuskan tujuan pembelajaran yang searah dengan pola belajar setiap siswa. Berkaitan dengan uraian tersebut, Slameto, memberi pengertian lebih spesifik tentang belajar, yang merupakan suatu proses usaha dilakukan seseorang untuk memperoleh perubahan tingkah laku yang baru secara keseluruhan, sebagai hasil pengalamannya sendiri dalam interaksi dengan lingkungan (Slameto, 2010: 2).

Dalam penjelasan tersebut ada tiga kata kunci belajar yang dapat disimpulkan, yaitu proses, hasil pengalaman dan perubahan tingkah laku. Dari ketiga kata kunci itulah belajar dapat dipahami sebagai sarana untuk mengubah perilaku seseorang menuju suatu peradaban yang mulia sebagai kelanjutan dari hasil pengalaman, akibat adanya interaksi dengan lingkungan, baik lingkungan keluarga, pertemanan dan masyarakat maupun lingkungan sekolah yang dilakukan melalui suatu proses edukasi yang panjang. Meskipun belum tentu setiap belajar dapat langsung menyentuh perilaku, karena secara teoretis proses belajar diawali dari mengubah informasi terlebih dahulu. Karena sebagaimana dijelaskan oleh Fajar, belajar dapat merupakan upaya merubah penjelasan mengenai informasi yang diperoleh lalu diproses dalam pikiran siswa (Fajar, 2009: 9). Pandangan seperti itulah yang seharusnya menjadi konsep dasar yang tertanam secara mendalam pada setiap pembelajar, agar setiap langkah belajarnya diawai dari suatu pemahaman yang prinsip tentang perubahan dan perkembangan.

Proses pengolahan informasi seperti penjelasan di atas itulah menjadi titik awal adanya proses belajar. Dari perubahan informasi akan memunculkan perubahan pengertian, dari perubahan pengertian selanjutnya diharapkan dapat 
mengubah sikap, dari sikap itulah yang menjadi dasar perubahan perilaku. Sehingga dengan pengertian tersebut, belajar diharapkan dapat meningkatkan pemahaman siswa sebagai salah satu wujud dari perubahan pengertian, perubahan sikap lalu perubahan perilaku. Jadi jelas sekali bahwa perubahan sebagai hasil belajar berawal dari perubahan informasi dalam pikiran, lalu mengubah pengertian dan sikap lalu masuk dalam ranah perilaku atau tindakan. Hanya masalahnya apakah setiap siswa yang belajar dapat memahami secara mendalam teori-teori tersebut di atas. Dan apakah setiap siswa yang belajar melakukan pekerjaannya dalam rangka mengubah perilaku dapat dikatakan belajar. Permasalahan itulah yang perlu ditelusuri secara mendalam pada pembahasan selanjutnya.

Sebagai suatu proses, belajar tidak dapat berjalan dengan baik apabila tidak diiringi dengan pengkondisian yang stabil. Gagne dalam Fajar megatakan bahwa untuk menuju suatu proses belajar yang berakhir pada perubahan, salah satu faktor diperlukan adalah kondisi yang stabil dan proses belajar yang stabil pula. Kondisi belajar yang dimaksudkan itu dapat bersifat internal maupun eksternal (Fajar, 2009: 9). Di dalam Islam saja kondisi yang dimaksud dijabarkan dengan lebar dalam hadis Rasulullah dengan enam syarat menuntut ilmu, sperti: cerdas, gigih, rajin, biaya (atau duit), bimbingan seorang guru dan membutuhkan waktu yang lama. Enam syarat menuntut ilmu tersebut menggambarkan secara riil kondisi seorang siswa yang dibutuhkan dalam belajar. Kestabilan kemampuan intelektual, kesungguhan dan kegigihan dalam belajar, daya juang dalam menuntut ilmu, kestabilan biaya sangat prinsip keberadaannya dalam belajar, agar upaya menuju perubahan sebagaimana disebutkan di atas dapat terwujud. Tetapi kestabilankestabilan tersebut belumlah cukup bilamana belum didukung oleh bimbingan guru dan waktu yang lama.

Melihat uraian di atas, pemahaman tentang kondisi belajar harus juga diperketat, karena kestabilan secara universal tentang belajar adalah kunci keberhasilan dalam belajar. Kondisi belajar yang tidak terkontrol dapat mengganggu proses belajar seseorang. Kondisi yang dapat membantu kesuksesan tersebut adalah kondisi yang harus berakar pada kestabilan internal dan eksternal siswa dalam belajar. Secara internal, ketenangan jiwa dan pikirannya dalam belajar menjadi pangkalnya kesuksesan dalam melanjutkan proses belajar. 
Kondisi tersebut sangat berarti, apalagi bila dihubungkan dengan syarat menuntut ilmu seperti digariskan dalam Islam seperti penjelasan di atas. Secara eksternal kondisi keuangan, hubungan dengan para pendidik terutama dalam proses pembelajaran. Hal ini dimungkinkan terjadi, dan tidak lain yang dimaksudkan itu merupakan upaya untuk meningkatkan kesadaran akademik siswa tentang belajar yang sebenarnya, bahwa belajar itu tidak sesusah yang diperkirakan dan tidak pula semudah dibayangkan oleh orang-orang yang kurang mengerti. Karena belajar itu adalah suatu proses panjang. Kestabilan jiwa merupakan kestabilan emosional dalam menuntut ilmu dalam rangka memperkuat pikiran. Sedangkan kondisi eksternal tidak lain adalah sesuatu yang ditata sedemikian rupa untuk membantu merangsang ingatan siswa agar tujuan pembelajaran yang telah dirancang dapat berjalan dengan lancar.

\section{B. Kajian Kegagalan Akademik Siswa di Sekolah}

Kajian-kajian tentang kegagalan akademik yang dihadapi oleh siswa sudah banyak dilakukan oleh para peneliti, seperti penelitian yang dilakukan oleh Jhonson menunjukkan bahwa secara umum siswa yang gagal dalam belajar tidak menunjukkan sikap satria, tidak suka pada tantangan, mereka cepat menyerah ketika menghadapi kesulitan, memiliki persepsi kontrol internal yang rendah terhadap keberhasilan dan kegagaalan dalam belajar. (Schunk, 2012: 522)

Sikap-sikap itu biasanya ditunjukkan oleh siswa, tidak berani menghadapi masalah beratnya belajar, belajar dalam pikiran mereka menyusahkan, banyak hapalan, banyak pekerjaan rumah. Belajar bagi mereka itu harus mudah dilakukan dengan santai saja, yang penting nilainya besar tanpa harus payah-payah mengejar nilai yang maksimal. Tidak perlu kerja keras karena guru dapat membantu keberasilan mereka. Di dalam ulangan tidak perlu belajar terlalu serius, karena mengerjakan soal-soal ulangan dapat bekerja sama dengan tema-teman yang lain. Di dalam ujian akhir tidak perlu ditakut-takuti, karena biasanya ada saja cara sekolah mengatasi kesusahan siswa, agar mereka tetapi berhasil dalam belajarnya.

Sikap-sikap tersebut diperparah dengan tidak suka pada tantangan belajar yang sulit, kontrol diri terhadap belajarnya sangat lemah. Tidak mengerti belajar itu untuk apa dan bagaimana belajar yang baik itu dilakukan, kapan seharusnya mereka mengulangi pelajaran dan bagaimana cara menambah kapasitas belajarnya agar kekurangan-kekuangan yang ditemukan di sekolah dapat ditambah melalui 
privat-privat. Tetapi sayangnya apa yang disebutkan terakhir ini tidak menjadi atensi siswa yang lemah kontrol dirinya dalam belajar, karena mereka tidak suka pada tantangan yang berat untuk dilakukan. Menambah jadwal belajar tambahan di luar jam belajar resmi menjadi beban berat bagi mereka. oleh karena itu apa yang diharapkan dari siswa seperti itu, tidak lain yang mereka kejar adalah tamat sekolah, dan lepas dari beban yang berat tersebut.

Faktor-faktor yang sebagaimana disebutkan di atas, bila dikaji secara mendalam tidak ada yang bersentuhan dengan eksternal siswa, karena semua yang disebutkan oleh Licht dan Kitsner adalah bermuara dari dalam diri siswa. Kesemua faktor tersebut pada satu sisi memberi dampak yang sangat signifikan terhadap keberhasilan belajar. Tetapi tidak sedikit dari para pendidik melupakannya atau bahkan belum memahaminya secara mendalam. Karena yang sering menjadi atensi pada pendidik, terhadap kegagalan gagal belajar siswa, bukan bersumber dari internal siswa, tetapi dilatarbelakangi oleh faktor-faktor di luar kehidupan belajar siswa seperti banyak bermain. Hal-hal yang bersentuhan dengan dengan kontrol diri yang rendah, tidak memiliki sikap satria dan selalu menghindari dari tantangan, belum dikaji secara mendalam oleh para pendidik sebagai bagian dari ikatan keberhasilan belajarnya siswa.

Faktor-faktor internal tersebut pada dasarnya tidak berarti apa-apa bilamana tidak didukung oleh keberhasilan interaksi edukatif dalam proses pembelajaran. Proses interaksi edukatif tentang suatu bahan pengajaran dinyatakan berhasil, apabila hasilnya memenuhi tujuan pembelajaran khusus bahan tersebut (Djamarah, 2002: 95). Dari situlah dapat diketahui bahwa keberhasil dan kegagalan belajar siswa di sekolah tidak selalu tertumpu pada faktor-faktor internal sebagaimana dijelaskan oleh Licht dan Kitsner, tetapi faktor ekternal turut serta dalam memberi dukungan atau hambatan dalam prosrs. Salah satu proses itu adalah interaksi edukatif yang ditempuh oleh siswa di dalam belajar. Apalagi bila dikaitkan dengan kondisi belajar siswa di sekolah dimasukkan dalam zona proximal development, yang masih membutuhkan bimbingan belajar terutama dari gurunya di sekolah. Boleh dikatakan bahwa bimbingan guru menduduki peringkat pertama dalam membantu keberhasilan belajar siswa. Itulah artinya bimbingan guru itu dapat berwujud pengkondisian belajar yang setabil bagaimana disebutkan 
di atas. Sedangkan bantuan teman dan orang tua menduduki peringkat selanjutnya.

Hambatan siswa dalam menuju tujuan belajar, sebagian besar bersumber dari dalam diri siswa itu sendiri, meskipun hambatan ekternal turut serta dalam memberi dukungan. Beberapa faktor internal seperti dijelaskan dalam pembahasan di atas, pertama adalah kegagalan akademik siswa berkaitan erat dengan siklus negatif kegagalan akademik yang pernah dialami oleh siswa sebelumnya. Pengalaman buruk belajar siswa yang pernah diraih sebelumnya, dan pernah membekas di pikirannya, dapat membuat siswa berhadapan dengan perasaan negatif akan kegagalan selanjutnya. Beberapa tokoh yang telah terlebih dahulu meneliti mengapa siswa itu sering gagal dalam belajar menunjukkan bahwa memang kegagalan belajar siswa dminan berakar dari dalam diri siswa. Penelitian Licht \& Kitesner mengatakan bahwa siswa yang memiliki masalah dalam belajar, semuanya berawal dari adanya siklus negatif, dan berinteraksi dengan kegagalan akademik sebelumnya. (Schunk, 2012: 522) Pandangan tersebut paling tidak menggaris bawahi bahwa pengalaman akan kegagalan sebelumnya menjadikan langkah selanjutnya terhambat oleh perasaan ketakutan akan gagal kembali.

Kemudian faktor kedua adanya anggapan yang tertanam dalam diri akan kelemahan dalam menghadapi masalah belajar. Pandangan ini mengindikasikan bahwa kegagalan belajar, sering dihubungkan dengan kerendahan kemampuan sehingga berdampak pada perasaan internal, ketidakmampuan melanjutkan studi, perasaan yang tidak mungkin dapat menyelesaikan masalah, sehingga terlambat dalam mengambil tindakan, ragu-ragu dalam mengambil sikap, tidak sanggup untuk mengekskusi tindakan apa yang harus dilakukannya, didorong pula oleh perasaan malas. Dampak lebih lanjut akan melekat dalam diri siswa, di mana efikasi diri untuk berprestasi tidak dapat muncul dalam dirinya Nolen, Hoeksema, Girgus \& Sleigmena, mengungkapkan Semuanya itu berdampak pula pada kekurang seriusan dengan pelajaran, guru bahkan sekolah dan sudah dapat dipastikan secara akademik, sikapnya terhadap pelajaran sangat rentan menurun sehingga prestasinyapun sulit meningkat. (Schunk, 2012: 522)

Faktor ketiga, secara internal usaha yang rendah dalam belajar menjadi sesuatu yang tidak dapat dianggap remeh, karena sikap-sikap tersebut turut besar peran sertanya dalam membangkitkan kegagalan siswa dalam belajar. Penelitian 
yang dilakukan oleh para peneliti seperti, Beorsama \& Cahpman (1981) Butkowsky \& Willows (1980), Chapman (1988), Palmer, Drummond, Tollison \& Zinkgraff (1982) menemukan bahwa siswa yang kurang "normal" secara akademik selalu berhadapan dengan masalah dalam belajarnya. Sikap tersebut tidak lain adalah usaha yang tidak bangkit dalam belajar. Konsentrasi belajar tidak selalu fokus pada belajar, tetapi lebih banyak dipengaruhi oleh hal-hal yang kurang prinsip, di luar faktor belajarnya, seperti faktor pertemanan dan permainan. (Schunk, 2012: 522)

Faktor Keempat adalah kontrol diri yang rendah. Sikap tersebut adalah kemampuan siswa untuk memahami arti belajar yang sesungguhnya sebagaimana disebutkan di atas menjadi akar masalahnya. Kemampuan memposisikan diri sebagai seorang pelajar, yang tugas utamanya adalah belajar dan menuntut ilmu belum teresap dalam diri seorang pelajar. Di samping itu ketidak mampuan siswa mengatur diri kapan mestinya dia belajar, dan kapan harusnya dia mengulangi belajar, dan kegiatan-kegiatan apakah yang menjadi prioritas dikembangkannya yang kelak menjadi milikinya tidak menjadi perhatian secara utuh bagi siswa tersebut. Hal-hal tersebut di atas paling tidak dapat memicu memperlemah poisisnya sebagai seorang belajar, yang seharusnya tugas utamanya adalah belajar.

Faktor kelima tidak menunjukkan sikap satria, faktor tersebut biasanya memperlihatkan gejala ketidak sanggupan siswa mengerjakan tugas, menghapal, melakukan kegiatan praktek, sikapnya ditunjukkan dengan sikap malas. Pikiran dan perasaannya seakan-akan tidak sanggup belajar, selalu takut dengan apa yang disebutkan dengan tugas. Diantara sikap itu adalah ketidaksanggupan siswa untuk menentukan dan sekaligus melakukan evaluatif dalam dirinya terutama terhadap terhadap kesulitan, kegagalan dan keberhasilan yang dicapai. (Siagian: 2004, 1119)

Faktor tersebut kelihatannya yang paling sulit dilakukan oleh siswa, meskipun dia dapat mengetahui dan memahaminya, bahwa dirinya memiliki tugas melakukan perubahan dan evaluasi terhadap dirinya sendiri, tetapi untuk melakukan perubahan yang signifikan dalam dirinya tidaklah mudah, karena siswa pada masa ini, sebagaimana disebutkan di atas, tujuan belajar yang ingin diraih sungguh kabur. Apa yang ingin dicapai tidak lain hanyalah keberhasilan, tetapi untuk menggapai keberhasilan itu terhambat oleh desakan-desakan skunder 
yang kadang-kadang tidak terkait dengan belajar mereka. Oleh karena itu fokus belajarnya bukan pada keberhasilan belajar tetapi sekolahnya harus tamat, bukan pada bagaimana belajar yang diraih itu menjadi bekal masa depan yang positif bagi perubahan dirinya dan perkembangan dirinya. Jadi keberhasilan belajar bukan diukur dengan nilai tetapi yang dikejar adalah bagaimana menamatkan sekolah.

Faktor keenam tidak suka pada tantangan, sikap siswa yang seperti itu biasanya memperlihatkan susah diarahkan untuk mengerjakan tugas, baik teoretis maupun praktek. Tantangan dalam pengertian di sini tidak lain adalah hambatan belajar yang dihadapi siswa bukan tantangan fisik dalam arti yang negatif. Tetapi bilamana pemahaman siswa tentang tantangan tersebut kabur, maka cara menghadapi tantangan belajar tersebutpun lebih kabur dari pada belajarnya. Artinya cara mengetahui dan mengendalikan hambatan dan tantangan belajar lebih kabur dari pada belajar yang dilakukan oleh siswa. Tantang belajar harus dihadapi oleh setiap orang, karena belajar tidak dapat dilakukan dengan mudah. Belajar butuh tanaga, belajar butuh waktu yang baik, dan belajar butuh. Pemahaman terhadap tantangan dalam belajar sangat sedikit diterima oleh siswa dari para gurunya. Salah satu tantangan itu adalah kesanggupan siswa konsisten terhadap belajarnya. Oleh sebab itu siswa-siswa yang tidak suka pada tantangan dalam belajar cepat sekali menyerah ketika menghadapi kesulitan.

Faktor ketujuh memiliki persepsi yang rendah terhadap keberhasilan dan kegagalan dalam belajar. Secara faktual ketidak berhasilan siswa dalam belajar, dengan beberapa gejalanya sebagaimanaa disebutkan di atas, gagal fokus pada pelajaran dan pemahaman tentang keberhasilan serta bagaimana cara menggapainya dengan baik menjadi sesuatu yang sangat sulit bagi siswa terebut. Perilaku siswa dengan gejala tersebut, menunjukkan gagal paham terhadap keberhasilan belajar. Jauh dari prestasi dan jauh dari hasil belajar yang memuaskan. Nilai sebagai salah satu tolok ukur keberhasilan belajar selau menunjukkan gejala yang mendatar, dan ada kesecenderungan menurun terus menerus. Sikapnya terhadap hasil belajar yang dicapai tidak menunjukkan gerafik yang positif.

Dari ketujuh faktor yang dijelaskan di atas, tentu dapat diketahui bahwa siswa-siswa yang mengalamai kegagalan dalam belajar pasti berhadapan minila 
salah satu dari faktor-faktor tersebut. Permasalahan selanjutnya apakah siswasiswa yang mengalami hal tersebt senantiasa berjalan seperti air mengalir, tentu pernah diinginkan oleh pendidiknya atau gurunya. Karena kagagalan siswa dalam belajar menjadi salah satu indikator kegagalan guru dalam mendidik. menghindari kegagagalan siswa dalam belajar, berarti menghindari kegagalan guru dalam mendidik dan mengajar.

\section{Kegagalan Langkah Menuju Keberhasilan}

Dari ke tujuh faktor tersebut sangat kontras dengan indikator keberhasil seorang dalam belajar. Tokoh seperti Slameto memaparkan beberapa indikator yang dapat dijadikan sebagai acuan untuk menentukan keberhasilan belajar yang telah ditempuh oleh seorang siswa. Beberapa indikator keberhasilan belajar tersebut, antara lain: terjadi secara sadar, bersifat kontinyu dan fungsional, bersifat positif dan aktif, bertujuan dan terarah dan mencakup seluruh aspek tingkah laku (Slameto, 2010: 2).

Pertama, Terjadi secara sadar. Hal inilah yang sering terjadi dengan kehidupan belajar siswa. Kesadaran akan makna belajar yang sebenarnya masih dangkal dalam pemahaman siswa. Belajarnya siswa pada umumnya belum menunjukkan hakekat belajar yang sebenarnya, karena proses belajar siswa senantiasa membutuhkan bimbingan, belum dapat dilepaskan dengan orang-orang sekitarnya. Hal inilah yang disebut masa belajar siswa disebut dengan zona proximal development. Keberadaan guru di sekolah, segala yang melekat dengan keguruannya adalah alat belajar bagi siswa, tidak saja ilmu pengetahuan yang dimiliki guru, tetapi guru itu sendiri secara utuh dan secara personalitas alat belajar bagai siswa. Demikian pula dengan keberadaan teman dan orang tua bagi siswa. Teman belajar adalah orang terdekat dengan siswa, biasanya mereka berusia sebaya memiliki wawasan, daya, kemauan dan keinginan tidak jauh berbeda antara satu dengan yang lainnya. Cara pandangan teman, cara belajar teman, kemampuan teman, dan keberhasilan teman dekat adalah alat belajar bagi teman-teman yang lainnya. Orang tua adalah sisi lain dari orang yang dekat dengan belajar siswa. Dapat dibayangkan kondisi anak-anak yang orang tuanya tidak ada, atau oleh karena kedua orang tuanya berpisah. Dapat dibayangkan kemampuan belajar siswa yang dimaksud. 
Kedua, Bersifat kontinyu dan fungsional, dalam arti bahwa belajar membutuhkan waktu yang cukup panjang. Belajar tidak dapat dilakukan dalam waktu singkat, belajar membutuhkan waktu terus menerus dan lebih dari itu belajar yang dilakukan dapat memberi arti penting bagi kehidupan. Mempunyai makna dalam arti memberi manfaat sebesar-besarnya bagi pengembangan diri dalam rangka memperluaskan dan melestarikan kebudayaan. Belajar pada intinya adalah pewarisan kebudayaan dari masa lampau ke masa yang akan datang.

Ketiga, Bersifat positif dan aktif, dalam pengertian belajar itu mengandung makna yang positif, baik ditinjau dari sisi objek, sarana, materi yang dipelajari, tujuan bahkan proses yang dilakukan pun harus mengandung sesuatu yang positif. Ditinjau dari sisi materi pelajaran tentu megandung manfaat untuk yang mempelajarinya. Oleh sebab itu mempelajari sesuatu yang tidak mengandung manfaat atau tidak berguna tidak dapat dikatakan belajar, seperti mempelajari ilmu sihir atau ilmu pelet. Hal-hal yang demikian karena tidak mendatangkan manfaat dan tidak ada positifnya. Di samping itu harus bersifat bereklanjutan. Karena makna aktif dalam proses pembelajaran menunjukkan suatu aktivitas yang tidak ada batas, baik ruang maupun waktu. Oleh karena itu keaktifan belajar menunjukkan sesuatu aktivitas yang senantiasa berkelanjutan dilakukan oleh seorang siswa maupun bukan siswa.

Keempat, Terarah pada seluruh aspek tingkah laku. Tidak lain adalah belajar dilakukan terukur, terprogram, sistematis dan dilaksanakan secara sistemik. Yang semuanya itu saling terikat satu sama lain. Belajar harus dilakukan melalui proses tersusun dari empat aspek pokok, yaitu tujuan, materi pelajaran, metode pembelajaran dan evaluasi pembelajarn. Keempat unsur inilah yang menjadi pokok proses pembelajaran. Bilamana keempat unsur tersebut telah tersusun dengan baik, tidak lain semuanya itu diarahkan untuk membentuk kepribadian peserta didiknya. Pembentukan tingkah laku sebagai hasil dari proses belajar tidak dapat dilakukan dengan baik bila keempata unsur itu itu hilang salah satunya.

Faktor ini menjadi sulit dikenali secara mendalam, sebab proses pembelajaran siswa di madrasah baik negeri maupun dui swasta menunjukkan gejala yang tidak jauh berbeda. Proses internalisasi dilakukan guru sulit digali secara empiris ilmiah, karena sebagian besar mereka lakukan kegiatan pembelajaran melalui penguatan aspek kognitif dan afektif. Penguatan terhadap 
perilaku sebagaimana disebutkan di atas masih perlu pendalaman teoretis, adalah gejala umum sebagai respon aktif terhadap pembelajaran kognitif dan afektif, sedangkan praktek keagamaan dilakukan hanya melalui kegiatan keagamaan formal, seperti solat berjamaah. Tentu hal ini lebih baik dari pada sekolah-sekolah yang tidak menerapkan kegiatan tersebut sama sekali

\section{Mengemas Faktor Kegagalan Menjadi Keberhasilan}

Di balik keberhasilan belajar, tidak semua siswa dapat meraihnya dengan baik, karena kesulitan belajar sarat ditemukan di sekolah oleh siswa-siswa tertentu. Kesulitan belajar adalah salah satu hambatan belajar yang sering ditempuh oleh seorang siswa. Dan kesulitan itulah yang dapat menjegal dan menjauhkan dirinya dari keberhasilan belajar. Walaupun kesulitan belajar sebagaimana dimaksudkan itu tidak berlaku sama untuk semua siswa, karena kesulitan tersebut bermacam-macam dan berbeda-beda tingkatannya. Dan cara siswa menghadapinya juga bervariasi polanya. Syaiful Bahri Djamarah dalam bukunya menguraikan tingkatan kesulitan belajar itu sangat bergantung pada jenis kesulitannya, mata pelajaran yang dipelajari, sifat kesulitannya dan faktor-faktor yang memunculkan kesulitan tersebut (Djamarah, 2011: 234-235).

Tingkat kesulitan belajar yang umum dihadapi oleh siswa adalah adaptasi terhadap pelajaran menjadi salah satu faktornya. Adaptasi itu dapat membawa siswa simpatik ataukah sebaliknya terhadap pelajaran tersebut. Sementara sifat kesulitan yang dihadapi siswa demikian pula, sangat variasi polanya. Siswa yang merasa sulit dalam belajar, tentu salah satunya terletak pada kemampuan mencernakan yang kaitannya dengan kemampuan siswa itu sendiri. Sehingga tidak sedikit pula kesulitan-kesulitan tersebut kadang-kadang menghadang siswa dalam belajarnya, kalau sekiranya kesulitan tersebut tidak dikemas secara akademis oleh para pendidiknya. Faktor-faktor belajar sebagaimana disebutkan di atas tentu berdampak pada dua hal pokok dalam diri siswa yaitu, ingin belajar atau malas belajar. Keberhasilan dan kegagalan sangat tergantung bagaimana mengemas faktor-faktor di atas menjadi sarana menuju keberhasilan ataukah kegagalan. Upaya mengiring kesulitan dari beberapa faktor tersebut ke ranah kegagalan belajar siswa, dan mencari sebab-sebabnya merupakan keniscayaan, tetapi mengkaji mengapa belajar siswa mengalami kegagalan, salah satunya 
disebabkan oleh ketidak jelasan pengemasan hambatan-hambatan belajar seperti tersebut di atas, terutama oleh para pendidiknya.

Kegagalan akademik tidak lain adalah gagal belajar yang diterima siswa yang disebabkan oleh berbagai faktornya pada suatu proses belajar tertentu. Kegagalan akademik singkat kata serupa dengan kegagalalan belajar yang diterima siswa dalam proses pembelajaran tertentu pada suatu proses pembelajaran tertentu pula. Kegagalan pengemasan itulah yang menyebabkan kegagalan belajar siswa, meskipun di samping itu didorong pula oleh masalahmasalah yang lainnya dalam belajar, terutama pengaruh negatif yang terus berputar sekitar dan saling berinteraksi dengan kegagalan akademik siswa (Schunk, 2012 : 522).

Banyak alasan bahkan banyak faktor mengapa kegagalan akademik sering melanda kehidupan siswa di sekolah. Selain apa yang telah disinggung di atas, faktor-faktor internal yang bersifat permanen menduduki pringkat utama dalam membangun sikap gagal belajar siswa. Para pendidik sulit sekali mendeteksi kegagalan tersebut, bahkan bagi siswa sendiripun tidak terlalu mendalam mendeteksinya. Di antara faktor-faktor yang paling krusial itu adalah disebabkan oleh siswa yang sering meragukan kemampuan belajarnya sendiri, dan mereka umumnya melihat kegagalan sebagai sesuatu yang tidak dapat dikontrol oleh mereka itu sendiri (Schunk, 2012: 522).

Apabila faktor-faktor tersebut tidak dapat dikemas dengan baik oleh pendidik atau guru, bukan tidak mungkin kegagalan tersebut menyebabkan siswa frustasi dalam belajarnya. Dan itulah yang dihawatirkan oleh para peneliti, seperti dijelaskan oleh Schunk dalam bukunya yang mengatakan bahwa akibat kegagalan belajar memunculkan frustasi dan menyerah (Schunk, 2012: 522) dalam diri siswa. Meskipun masih banyak lagi faktor yang lainnya, seperti dikemukakan oleh Schunk, faktor kurangnya usaha dan keuletan, turut memberi kontribusi yang signifikan pula dalam menentukan kegagalan lebih lanjut (Schunk, 2012: 522). Dari kedua penjelasan terakhir ini menujukkan bahwa kegagalan belajar siswa dapat disebabkan oleh gagal paham tentang tujuan belajar, kurang usaha dan keuletannya dalam belajar dipertanyakan, yang kesemuanya itu berdampak pula pada sikap frustasi dan menyerah pada keadaan yang sedang dihadapi. 
Dari uraian di atas dapat disimpulkan bahwa faktor-faktor tersebut selanjutnya dapat memperkuat dugaan dalam diri siswa bahwa belajar itu berat dan selanjutnya berdampak pada sikap menyerah. Di samping siswa tertentu biasanya memiliki masalah, seperti perkiraan yang sangat rendah akan kesuksesan, menilai diri sendiri memiliki kemampuan yang sangat rendah, sehingga tidak mungkin dapat menggapai keberhasilan (Schunk, 2012:522). Melihat gejala seperti itu bukannya menjadikan siswa bertambah semangat dalam belajar, tetapi sebaliknya dapat menjadikan siswa susah sekali bangkit dalam belajarnya, karena semua paradigma akan kegagalan akadmik niscaya berakar pada perasaan mereka yang sumir, emosi dan motivasinya tidak pernah terangkat oleh keberhasilan orang yang berhasil.

Pandangan yang sama tentang kegagalan tersebut dikemukakan oleh Jhonson dan Licht \& Kistner mengatakan kegagaaan siswa berakar pada emosi siswa itu sendiri, yaitu mudah menyerah ketika meghadapi kesulitan, tidak dapat membangun suatu asumsi sebuah keberhasilan. dari sinilah dapat ditelusuri bahwa asumsi akan kegagalan berakar dalam diri mereka sendiri di samping memang perspesi mereka yang rendah terhadap kontrol internal atas hasil yang mereka capai (Schunk, 2012: 522). Dari penjelasan-penjelasan tersebut dapat dikatakan bahwa kegagalan akademik siswa dapat disebabkan oleh adanya sikap dari dalam internal siswa untuk menyamarakan kepercayaan negatif yang pernah dialami ke dalam situasi di mana mereka itu gagal sebelumnya (Schunk, 2012: hlm.522). Sehingga akibatnya tidak ada upaya untuk bangkit dari kondisi yang menyeramkan tersebut.

Selain dari apa yang disebutkan di atas, pengemasan faktor-faktor kegagagalan seperti diuraikan di atas menjadi faktor utama menghindari kegegalan belajar. Salah satu caranya, bagi para pendidik harus dapat mengemas faktor-faktor tersebut tidak selalu bersemayam dalam diri siswa. Dan mencari cara yang tepat agar faktor-faktor tersebut tidak menjadi hambatan terbesar belajar siswa. Siswa senantiasa dijauhkan dari sikap-sikap negatif ketika belajar berlangsung. Beberapa faktor tersebut secara asumtif jangan jadikan siswa berlama-lama dalam kondisi tersebut. Siswa harus diberi semangat dan pemahaman yang mendalam bahwa kegagalan adalah pangkal keberhasilan. 


\section{E. Umpan Balik Alternatif Pemecahan Kegagalan Akademik}

Siswa yang mengalami masalah kegagalan sebagaimana diuraikan di atas tidak dapat dibiarkan belajarnya seperti air mengalir, harus ada upaya sistematis akademis agar kondisi siswa tersebut dapat berubah ke situasi yang lebih memungkinkan dia dapat belajar dengan serius dan dapat menguntungkannya. Sebagai sebuah fenomena, siswa yang mengalami masalah kegagalan dalam belajarnya dapat terjebak dalam kegagalan belajar secara total. Untuk itu teoriteori yang berkaitan dengan proses belajar siswa dapat digunakan untuk mengupas kegagalan siswa dalam belajar sebagaimana dimaksudkan oleh teori tersebut.

Ada beberapa indikator siswa yang mengalami kegagalan dalam belajarnya, namun secara umum sebagian besar siswa tersebut menunjukkan ketidak berdayaannya dalam mengatasi dirinya sendiri. Hal ini terkait pula dengan tingkatan ego yang ada dalam dirinya yang cenderung meninggi, seperti halnya dikemukakan oleh Dwek bahwa ciri-ciri ketidak berdayaan siswa dimaksud tampak dalam tidak ada upaya yang konkrit dan terkontrol dengan situasi belajarnya sebagaimana disebutkan di atas. Salah satu faktor dominan yang menyebabkan hal tersebut adalah mereka memahami tujuan sekolah mereka lakukan adalah sebagai upaya untuk menyelesaikan tugas, dan menghindari penilaian negatif atas komptensi mereka miliki (Schunk, 2012: 522).

Lebih lanjut Dinner dan Dweck, megatakan bahwa siswa-siswa seperti itu biasanya mengghindari tantangan, menunjukkan keuletan yang rendah dalam menghadapi kesulitan, memegang persepsi yang rendah mengenai kemampuan mereka dan selalu dihadapkan dengan kecemasan dalam menghadapi tugas (Schunk, 2012: 522). Dari pernyataan bebeapa ahli di atas dapat dinyatakan bahwa kegagalan akademik seorang siswa dalam belajarnya sebagian besar berakar dari dalam diri sendiri bukan berakar pada orang lain, atau sebab lain seperti atau orang tua, atau guru. tetapi motivasi orang tua penting dalam nenunjang keberhasilan belajar siswa. Apalagi motivasi guru jauh lebih urgan lagi, karena melalui pembelajaran gurulah siswa memiliki semangat dalam belajarnya, ataukah sebaliknya.

Di samping masalah kegagalan para tokoh banyak juga yang membahas bagaimana cara memperkecil kegagalan tersebut agar kegagalan belajar tidak berdampak buruk pada kegagalan sekolah. Dua istilah dalam pendidikan mirip 
sama tetapi ditinjau dari sisi etimologis dan terminologisnya berbeda. Seperti Freidman dan Medway yang berupaya mengkaji beberapa variabel yang terkait dengan lingkungan di mana situasi belajar siswa itu berada, situasi tersebut pada satu sisi dapat mencegah siswa agar tidak memiliki masalah dengan belajarnya, sehingga selanjutnya dapat memasuki pada suatu fase mengatasi masalah-masalah dalam belajar (Schunk, 2012:523). Upaya tersebut kelihatannya tidak lain merupakan upaya mencegah agar siswa tidak terjebak dalam kegagalan dalam belajar yang tidak berkelanjutan. Untuk itu Dalam tulisan ini akan dikaji satu sisi agar supaya siswa tidak banyak mengalami kegagalan dalam belajarnya. Satu hal yang sangat ugen yang pada dasarnya sudah sering dialkukan guru, yaitu "umpan balik". Hanya saja artikulasi umpan balik sebagai konsep teoretis proses pembelajaran siswa belum dikaji secara mendalam sebagai teknik ilmiah sebagai pencegahan terhadap kegagalan belajar siswa. Keadaan ini disebabkan oleh persepsi guru tentang umpan lebih diminan dipahamai sebagai strategi semata, bukan sebuah teori.

Memberi umpan balik dengan tepat dan ilmiah, seharusnya menjadi sebuah atribusi khusus dapat digunakan secara khusus oleh guru dalam mencegah kegagalan belajar siswa. Paling tidak umpan balik harus dapat dimaknai oleh guru secara ilmiah sebagai cara khusus memberi atensi serius dalam menangani permasalahan belajar siswa. Umpan balik tidak hanya dimaknai sebagai proses, tetapi umpan balik harus dimaknai sebagai teknis khusus, kiat khusus, dan strategi khusus memberi pelayanan khusus untuk mengurangi miskomunikasi guru dengan siswa, mengurangi misatensi siswa terhadap penjelasan guru. Melalui atribusi tersebut niscaya dapat mengubah keyakinan dan perilaku berprestasi bagi siswa yang maladaptif dengan belajarnya, sehingga menjadi adaftif yang positif. Oleh karena itu guru sebagai salah satu atributor pembelajaran, yang menurut Schunk adalah di antara variabel-variabel pembelajaran, harus berperan maksimal terhadap pembelajaran siswa. Di antara peranan itu adalah memberi tugas yang bisa dikerjakan oleh siswa dan memberi umpan balik menyoroti kemajuan ke arah pencapaian tujuan pembelajaran (Schunk, 2012: 523). Oleh sebab itu umpan balik tidak dapat dimaknai sebagai peroses, bahkan lebih dari itu, umpan balik harus dapat dijadikan sebagai model pembelajaran yang khas. 
Untuk mngkritisi pendalaman terhadap makna feed back yang positif harus dilakukaan seorang guru dengan melakukan berbagai strategi, khususnya yang berkaitan dengan itu adalah memberi Tugas. Memberi tugas jangan dimaknai sebagai memberi ulangan, atau melepas beban kekurangan guru yang tidak terselesaikan di kelas, tetapi tugas harus dilaksanakan secara proporsional dan profesional, karena tugas bukan sekedar tugas, kunci utamanya bukan pada tugasnya tetapi cara memberi tugasnya yang harus mencirikan sebagai sebuah strategi. Pandangan tersebut dipertegas oleh Stipek dan Kowalski (1989) yang menemukan bahwa strategi tugas pada anak atau siswa yang tidak mementingkan usaha akan menaikkan kinerja akademiknya (Schun, 2012: 523). Di sini tugas dilakukan bukan dengan maksud membebankan siswa tetapi adalah sebuah proses pematangan, proses penguatan terhadap informasi yang telah didapati,bahkan lebih dari itu tugas harus dapat dimaknai sebagai langkah untuk menemukan sesuatu yang baru. Oleh sebab itu tugas harus dilakukan secara sitematis dengan metode yang tepat sesuai dengan kebutuhan siswa.

\section{KESIMPULAN}

Dari penjelasan pajang lebar di atas pada bagian akhir, dapat disimpulkan bahwa belajar sebagai modal dasar perubahan manusia, dalam kehidupan siswa adalah pondasinya pembangunan akademik. Membangun akademik siswa yang baik dapat menghindarkan mereka gagal dalam belajar. Membangun akademik siswa yang positif dapat membantu siswa dari kegagalan lebih jauh sehingga terjebak dalam kegagalan sekolah. Penting mengkaji secara mendalam faktorfaktor kegagalan tersebut. Banyak sekali faktor-faktor yang menyebabkan siswa gagal dalam belajar. Paling sedikit penjelasan di atas mengungapkan ada beberapa indikator yang menyebabkan kegegalan belajar yang dilakukan siswa.

Namun demikian semua indikator kegagalan belajar siswa tersebut di atas semuanya berakar dari dalam diri siswa, walaupun ada yang berkaitan dengan faktor di luar diri siswa, tidak lain faktor tersebut adalah yang berkaitan dengan perkembangan kepribadian siswa itu sendiri. Kemampuan mengemas faktorfaktor kegagalan siswa tersebut dapat menjembatai keberhasilan belajar siswa. Pertama mengemas negativisme kegagalan itu menjadi keberhasilan, salah satunya adalah memberi atensi yang serius kepada siswa, bahwa faktor -faktor 
kegagalan tersebut tidak menjadi hambatan belajar siswa. Tetapi jadikanlah hambatan itu secbagai pemicu keberhasilan.

Pada dasarnya banyak cara mengemas kegagalan akademik siswa dalam belajar, hanya saja para pendidik sering melupakan apa yang seharusnya mereka hadapi itu sebagai cara yang efektif. Seperti meberi tugas atau resitasi. Para pendidik umumnya memahami hal tersebut sebagai hal yang biasa di dalam belajar. Asumsi ini terjadi karena resitasi belum diletakkan sebagai teknik ilmiah sebagai pemecah kebuntuan belajar siswa, Tetapi resitasi atau penugasan dianggap hal yang biasa. Karena asumsinya biasa, maka membelajarkaan siswa dengan resitasi menjadi pekerjaan yang biasa, sehingga tidak ditemukan teknikteknik ilmiah dilakukan.

Kegagalan siswa berakar dari lemahnya pemahaman tujuan belajar, kontrol diri yang rendah dan biasaanya dapat pula disebabkan oleh bayang-bayang kegagalan yang berkelanjutan, sehingga tampak ketidak berdayaannya dalam menghadapi masalah belajarnya. Untuk mengatasi hal tersebut, atribusi positif dengan feed back yang positif pula melalui suatu upaya memberian tugas atau resitasi yang tepat, niscaya kegagalan belajar dalam suatu pembelajaran tertentu dapat diminimalkan. 


\section{DAFTAR PUSTAKA}

Djamarah, Syaipul Bahri, Psikologi Belajar, Jakarta: Rineka Cipta, 2011. , Guru dan Anak Didik dalam Interaksi Eukatif Suatu Pendekatan Teoretis Psikologis, Jakarta:Rineka Cipta, 2002.

Fajar, Arnie, Portopolio dalam Pelajaran IPS, Bandung: Remaja Rosda Karya, 2009.

Fatimah, Ahmad Khoiri, al-Akhlak al-Islamiyah, Beirut, Dar fikri, 1999.

Rahyubi, Heri, Toeri-teori Belajar dan Aplikasi Pembelajaran Motorik Deskripsi dan Tinjauan Kritis, Majalengka; Referens, 2012.

Schunk, Dale H., Learning Theories, An Educational Persefective: Teori-teori Pembelajaran persfektif Pendidikan, Terjemahan oleh Eva Hamidah dan Rahmat Fajar, Yogyakarta: Pustaka Pelajar 2012.

Siagian, P. Sondang, Teori Motivasi dan Aplikasinya, Jakarta: Rineka Cipta, 2004. Slameto, Belajar dan Faktor-Faktor yang Mempengaruhi , Jakarta: Rineka Cipta, 2010. 